\title{
Ethnoagroforestry management and soil fertility in the semiarid Tehuacán Valley, México
}

José Bernardo García-Licona ${ }^{1}$, Ranferi Maldonado-Torres ${ }^{2}$, Ana Isabel Moreno-Calles ${ }^{3}$, María Edna Álvarez-Sánchez ${ }^{3}$, Juan García-Chávez ${ }^{4}$, Alejandro Casas ${ }^{5}$

\begin{abstract}
Ethnoagroforestry practices and their relationship with soil fertility were studied in the semiarid Tehuacán Valley. Such practices involve management of manure, vegetation patches, wild and cultivated plants, soil, and water. This study aimed to: i) describe agroforestry management practices that influence soil fertility in maize multicultural system (milpa)-cacti forest (chichipera) AFS; ii) analyze the status of soil fertility in cultivated areas of these AFS; and iii) analyze the influence of agroforestry practices on soil nutrimental parameters of cultivated areas. In depth interviews were conducted, along with participatory tours with peasants and soil sampling in the agroforestry plots. Ethnoagroforestry practices favor adequate levels of macronutrients and organic matter in the milpa-chichipera AFS, despite $\mathrm{Fe}, \mathrm{Cu}$, and $\mathrm{Zn}$ deficiencies. The supply of organic matter is fundamental because it preserves soil fertility and moisture in all the plots studied. Smallholders (43\%) use manure, but in irregular and insufficient way. Only $27 \%$ of interviewed people leave the land fallow for 1-2 after periods of 24 years of use, which does not allow the soil to reestablish fertility. Smallholders practice wild vegetation management, enabling $90 \%$ of plots to reach a high level of vegetation cover (>25\%), furthermore $33 \%$ of agroforestry plots depend exclusively on this management to reestablish soil fertility. Labor force, economic conditions and plots characteristics influence agroforestry management. The amount of manure and the interaction between the agroforestry practices (vegetation cover, type of agroforestry practices, amount of manure, and fallow years) are related to the presence of $\mathrm{N}, \mathrm{K}, \mathrm{Cu}$ and $\mathrm{B}$ in the soil. To maintain and improve soil fertility in the milpa-chichipera AFS is important to consider local practices, biophysical conditions, and socio-economic factors.
\end{abstract}

Keywords: Traditional agroforestry, semiarid ecosystem, manure, fallows, vegetation management, San Luis Atolotitlán Puebla.

1 Centro de Estudios Superiores Indígenas Kgoyom, Calle Vicente Guerrero sin número, Colonia centro, Apartado Postal 73470, Huehuetla, Puebla, México. E-mail: bernardo_garci@hotmail.com

2 Departamento de Suelos, Universidad Autónoma Chapingo. Kilómetro 38.5 Carretera México-Texcoco, Apartado Postal 56230, Texcoco, Estado de México, México.E-mail: ranferimt@hotmail.comand edna_alvarez30@yahoo.com.mx

3Escuela Nacional de Estudios Superiores Unidad Morelia. UNAM, Campus Morelia, Antigua Carretera a Pátzcuaro No. 8701, Col. Ex-Hacienda de San José de la Huerta, Apartado Postal 58190, Morelia, Michoacán, México. E-mail: isabel_moreno@enesmorelia.unam.mx

4 Escuela de Biología, Benemérita Universidad Autónoma de Puebla. Edficio 112A, Ciudad Universitaria, Avenida San Claudio y 18 Sur, Colonia San Manuel, Apartado Postal 72570, Puebla, Puebla, México. E-mail: juanga@correo.buap.mx

51 Instituto de Investigaciones en Ecosistemas y Sustentabilidad. Universidad Nacional Autónoma de México (UNAM), Antigua Carretera a Pátzcuaro 8701, Col. San José de la Huerta, Morelia, Michoacán 58190, México. acasas@cieco.unam.mx

*Corresponding author:isabel_moreno@enesmorelia.unam.mx1 


\section{INTRODUCTION}

Ethnoagroforestry systems are ancient and modern wisdoms, knowledge and practices involved in food production, biodiversity, biocultural and agrodiversity conservation (Casas et al. 1997, 2007; Moreno-Calles et al. 2013, 2016a,b; Toledo and Barrera-Bassols 2008). These systems have been characterized to harbor high crop diversity, low external inputs, high labor intensity and technologies locally adapted (Altieri 1991; Altieri and Nicholls 2005; Pretty 1995). These systems allow the management of lands considered unproductive and mitigate the impact of natural and anthropogenic changes, by conserving local resources such as water, soil, and biodiversity (Altieri 2004; Palerm 1997). Additionally, this kind of agroforestry has contributed to people's self-sufficiency for centuries in rural contexts (Altieri 2004; Altieri and Nicholls 2005; Toledo et al. 2003).

Dryland areas (arid, semiarid and sub humid) are low and variable precipitation, low soil fertility, vulnerability to resource degradation and high evapotranspiration (Ffolliott et al. 1995; Hagin and Tucker 1982; Reynolds et al. 2005). Specifically, soils tend to be lower in organic matter, thereby containing less mineralizable $\mathrm{N}$; higher in $\mathrm{Ca}, \mathrm{Mg}$ and $\mathrm{K}$, lower in $\mathrm{P}$; and micronutrients (Chapin et al. 2002; Hagin and Tucker 1982; Whitford 1993). Nearly $40 \%$ of the world's population lives in dryland regions and depends on agricultural and forestry management to satisfy their needs (Ffolliott et al. 1995; Koohafkan and Stewart 2008; Parr et al. 1990). Mexico has nearly $60 \%$ of its territory occurring in arid, semi-arid and sub-humid environments, these areas, lodge about $40 \%$ of the biodiversity of the country and most endemic species and harbor high human cultural richness, being inhabited by 30 of the 58-main indigenous ethnic groups
(Casas et al. 2010).

The influences of population growth, inadequate governmental policies, changes in land tenure, and chaotic changes in land use have synergistically caused soil degradation and loss of productivity (Jock and Dillon 1992; Koohafkan and Stewart 2008; Parr et al. 1990). In addition, where these regions are affected by increasing of aridity, the most common consequence is desertification (Kassas 1995; Reynolds 2005). Most drylands of the world are in process of desertification, which results in migration, loss of traditional cultural and ecological knowledge and socioeconomic changes (Altieri and Toledo 2005; Reynolds 2005). Frequently, the action implemented from governmental programs have been ineffective to find solutions because desertification is a complex process and each location is generally affected by different causes (Geist and Lambin 2004; Reynolds 2005).

Therefore, projects that analyze and encourage sustainable management are essential to achieving food sovereignty and biodiversity conservation (Koohafkan and Stewart 2008; Parr et al. 1990). Smallholders have adapted traditional practices to dryland conditions to maintain soil fertility for food production (Harris 2002; Haileslassie et al. 2006; Reynolds et al. 2005; Williams 1999). In Mexico, agroforestry systems (AFS) of dryland areas have as main traditional management methods fallows, manure, and organic matter contribution from plants (Cariño et al. 2012; Granados-Sánchez et al. 2004; Maya et al. 1997; Moreno-Calles et al. 2013; Palerm 1997). Documenting such methods is a priority research to contribute to improving traditional AFS, it is important to characterize the management practices that maintain soil fertility and conduct a 
diagnostic of soil fertility conditions. Furthermore, no studies have been found on the interaction between traditional agroforestry practices in arid ecosystems and soil fertility.

In the Tehuacan Valley, several studies have focused their attention on the role of ethnoagroforestry systems (Moreno-Calles et al. 2013) in biodiversity management from biocultural perspectives (Campos-Salas et al. 2016; Moreno-Calles et al. 2010, 2012; Vallejo Ramos et al. 2015, 2016). However, little attention has been directed to analyze the relevance of this biocultural diversity for environmental benefits of agriculture such as the maintenance of soil fertility. The milpachichipera AFS is a polyculture that interacts with columnar cacti forests (in which the columnar cacti chichipe, Polaskia chichipe, chende (Polaskia chende and garambullo, Myrtillocactus schenckii predominate) of the semiarid regions of the Tehuacán Valley, México. It is a provider of goods and benefits like wild vegetation cover in the plots, richness and endemic species conservation and social and environmental benefits to local and regional levels (Moreno-Calles et al. 2010, 2012).

The relation between ethnoagroforestry practices, the vegetation cover of plots, the biodiversity as well as the biocultural diversity maintained in the systems, and their role with the conservation of soil fertility in this AFS has not been studied. Our research therefore aimed to: i) describe agroforestry management practices that influence soil fertility in the AFS; ii) analyze the fertility status of the cultivated areas in the milpa-chichipera AFS; and iii) analyze the influence of agroforestry practices on the nutrimental parameters of the cultivated areas. We generally hypothesized that the increase of manure, fallow and vegetation cover in the plots would raise the levels of soil nutrients.

\section{MATERIAL AND METHODS}

\section{Study area}

The Tehuacán Valley in central México belongs to Tehuacán-Cuicatlán Biosphere Reserve, comprising an extent of approximately 10,000 km2 (Casas et al. 2001). In this region characterized by high biodiversity, nearly 2,800 plant species and 1,600 useful plant species have been registered (Blancas et al. 2010; Dávila et al. 2002; Valiente-Banuet et al. 2006). In the dry region of the Valley, AFS has been studied in the towns of San Luis Atolotitlán, San Rafael Coxcatlán and Santiago Coatepec; these AFS are seasonal multi-crops that interact with columnar cacti such as Polaskia chende, and $P$. chichipe and Myrtillocactus schenckii referred to above, as well as jiotilla (Escontria chiotilla) and pitayas (Stenocereus stellatus and S. pruinosus) (Moreno-Calles and Casas 2008; MorenoCalles et al. 2010).

This study was conducted in the town of San Luis Atolotitlán, Puebla, México (Figure 1 ), a semiarid zone with a territory of 10,880 ha, elevations from 1,100 to $2,554 \mathrm{~m}$, average annual rainfall of $407.2 \mathrm{~mm}$, and average temperature of $210 \mathrm{C}$. The most widespread vegetation in its territory is chichipera forest, dominated by $P$. chichipe and $P$. chende, found at elevations from 1,700 to $2,300 \mathrm{~m}$. The chichipera forest grows on volcanic soil, which is better for agriculture than the limestone soil which are predominant in the region (Moreno-Calles et al. 2012). The community of 1,374 inhabitants are "Mestizo" people and land ownership is communal under the Ejido system. Agriculture is the primary economic activity, encompassing approximately 1,500 
ha, of which $90 \%$ is rainfed. The milpachichipera AFS is a traditional multi-crop of maize, beans and squash that interacts with forests of chichipera, covering 922.5 ha, which represents $61.5 \%$ of the agricultural land of the territory of the community. This AFS provides crops, firewood, edible plants and animals, medicines, and construction material for local households' subsistence (Moreno-Calles et al. 2012). In addition, its vegetation provides 128 species of plants

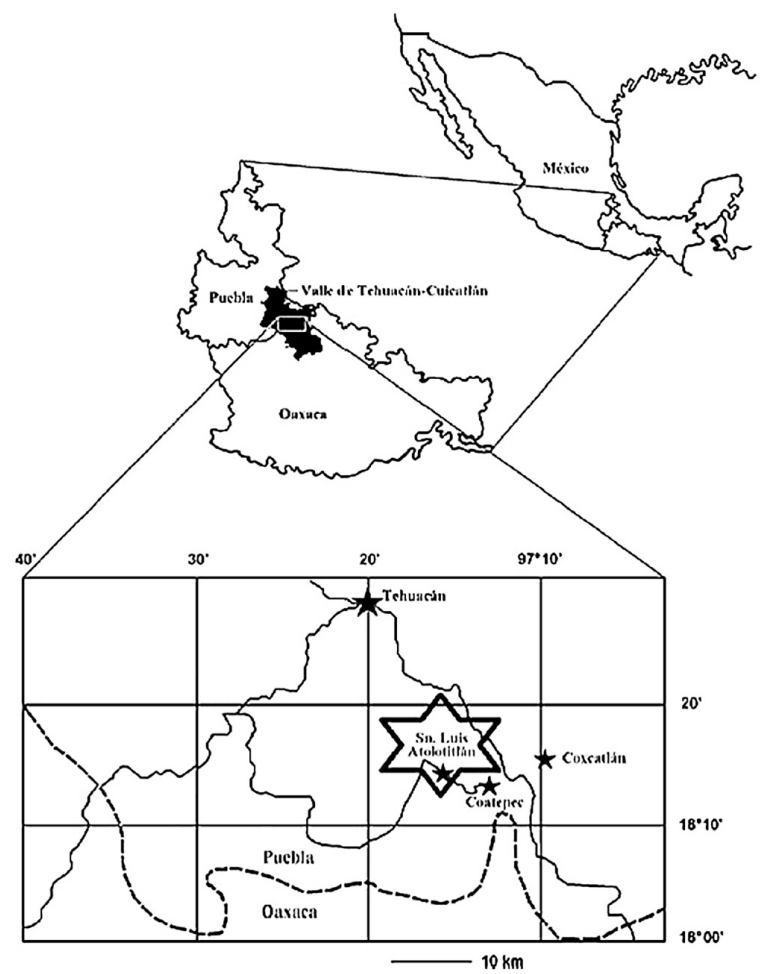

Figure 1. Location of San Luis Atolotitlán in the Tehuacán Valley, Puebla México

used as livestock fodder, including weeds, bushes, and trees (Torres 2004).

\section{Agroforestry Management}

From approximately 80 smallholders with milpa-chichipera AFS, a sample of 30 households was selected randomly and their heads interviewed about different topics related to the traditional managements and their practices that influence agricultural soil fertility. Based on previous reviews on management of AFS y dryland areas, the interviews focused on the traditional practices in these AFS of drylands and their role for restoring soil fertility. According to previous studies, a key factor is maintaining wild vegetation, which provides organic matter and livestock fodder, and restores soil fertility. Particularly important are elements of vegetation with high capacity of fixing nitrogen and those having mycorrhizal interactions. Livestock fodder transformed into manure accelerates and concentrates soil's nutrients, while fallows restore soil fertility. For these reasons, the interview consisted on the following sections: i) wild vegetation management, ii) livestock and manure management, and iii) fallow management. We analyzed our results through a data table. The information obtained on wild vegetation management was complemented by the calculation of vegetation cover. The calculation of plot area based on data from titles named "PROCEDE" or by field measurement. In each plot, cultivated lands were measured by adapting a geometric figure to calculate total area. Finally, the vegetation percentage was calculated using the proportion of cultivated area in relation to the total plot area.

\section{Soil fertility analysis}

A total of 65 active AFS plots were identified, and 20 of them were randomly selected for the analysis of the study. In the cultivated area of each plot, a composite sample was collected before the sowing season (June 2013). In the laboratory, each composite sample was dried, ground and sifted. Based on the procedures described in the NOM-021-2000 for soil fertility analysis 
(SEMARNAT 2002). Each sample was processed to determine the following factors: texture using the Boyoucos method, $\mathrm{pH}$ of soil-water relation 1:2 (with a potentiometer), electric conductivity (EC) determined in the $\mathrm{pH}$ extract (soil-water relation 1:5), cationic exchange capacity (CEC) with $\mathrm{CH}_{3} \mathrm{COONH}_{4}$ $1 \mathrm{~N} \mathrm{pH}=7$ and organic matter (OM) by the Walkley and Black method. In addition, the following nutrients were quantified: total nitrogen $(\mathrm{N}-\mathrm{t})$ by the Kjeldahl method, inorganic nitrogen $\left(\mathrm{N}-\mathrm{i}: \mathrm{NO}_{3}+\mathrm{NH}_{4}\right)$ extracted with $\mathrm{KCl} 2 \mathrm{~N}$ and quantified by steam distillation; available phosphorus $(P)$ by the Olsen method; potassium (K) by flame photometry; calcium $(\mathrm{Ca})$ and magnesium (Mg) by atomic absorption spectrophotometry; copper $(\mathrm{Cu})$, iron $(\mathrm{Fe})$, manganese $(\mathrm{Mn})$ and zinc $(\mathrm{Zn})$ extracted by DTPA and quantified by atomic absorption spectrophotometry; Boron (B) extracted by $\mathrm{CaCl}_{2}$ 1.0M and quantified by azomethine- $\mathrm{H}$. Physicochemical parameters were interpreted based on Ankerman and Large (1977).

\section{Statistical analysis}

To identify the possible impact of traditional management practices on nutrimental parameters ( $\mathrm{N}-\mathrm{t}, \mathrm{N}-\mathrm{i}, \mathrm{P}, \mathrm{K}, \mathrm{Ca}$, $\mathrm{Mg}, \mathrm{Cu}, \mathrm{Fe}, \mathrm{Mn}$ and $\mathrm{Zn}$ ), a multivariate analysis of variance (MANOVA) was conducted with the Pillai's Trace method (Quinn and Keough 2002; Scheiner 2001). The traditional agroforestry practices: vegetation cover percentage, amount of manure applied and fallow years were selected as independent variables, because they increase the presence of soil nutrients (Harris 2002; Styger and Fernandes 2006; Young 1997). Box-Cox transformations were applied to non-normally distributed variables according to Krebs (1998). If the MANOVA conveyed a significant result, relations were examined separately through one-way analysis of variance (ANOVA). Statistical analyses were realized with the $R$ statistical software version 3.0.3 (R Development Core Team 2011), considering $\alpha=0.05$.

\section{RESULTS AND DISCUSSION}

\section{Wild vegetation management}

Mainly from 1925 to 1985, local authorities permitted the clearing of plots to initiate cultivation. Clearing consists in selecting the area in the plot with the best conditions for cropping, such as deep soil, relative absence of stones and a gentle slope. Areas in the plot with shallow, stony soil or a steep slope are not cultivated and vegetation is tolerated there (Figure 2). Once an area is selected for cultivation, all weeds and bushes are removed with the tool called "tlalacho" (pickaxe) and, if necessary, a "machete" is used to cut the plant roots. Certain perennial plants like coahuino (Schinus molle), mezquite (Prosopis laevigata), chichipe (P. chichipe), chende (P. chende) and others are tolerated in the cultivated area because of their importance for use by families. All the smallholders interviewed apply this practice, and $33 \%$ of them depend exclusively on the contribution of organic matter from vegetation to reestablish soil fertility. Regarding the presence of wild vegetation in the plot, $40 \%$ of the farmers think that it is beneficial, because it provides green manure that is naturally transported by rainwater to the cultivated area, and it helps to retain soil. The rest think that the vegetation has a negative influence, as it competes with crops for water, sunlight, and nutrients. 


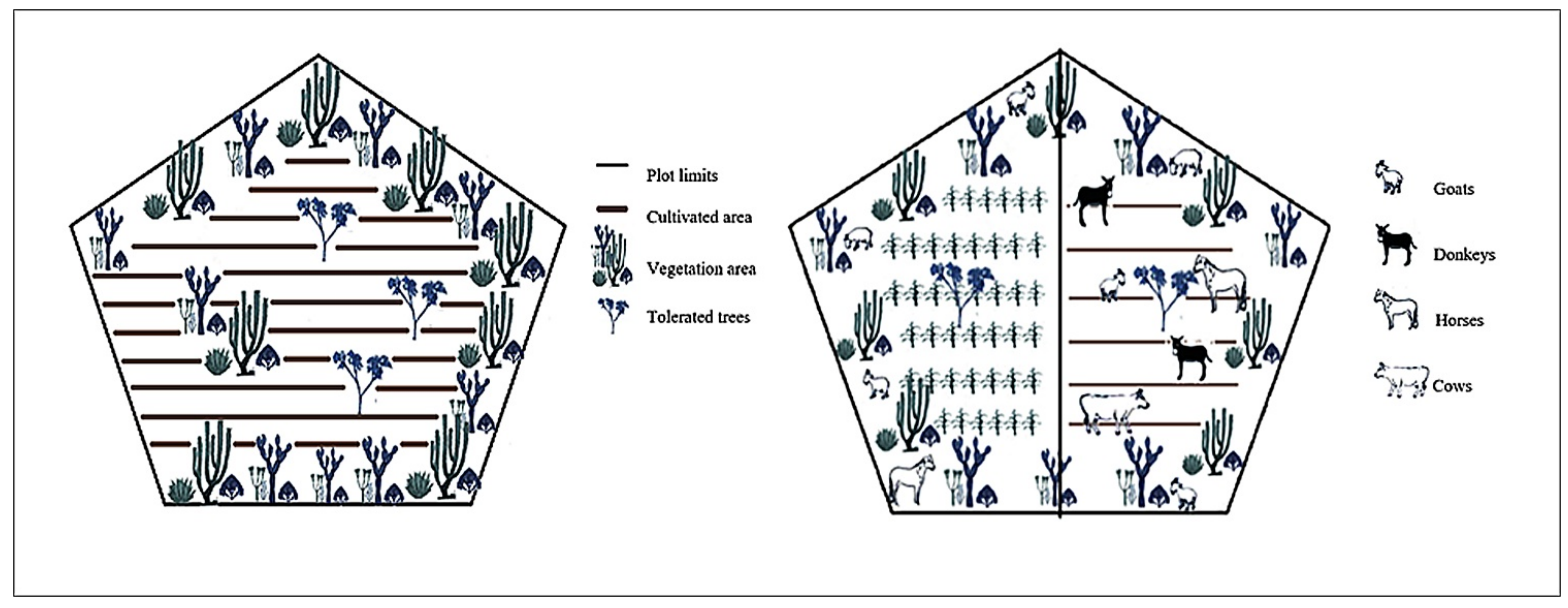

Figure 2. Configuration of cultivated area, ethnoagroforestry practices and vegetation in the plot and Presence of livestock in two different seasons of the year.

\section{Livestock and manure management}

To recovering soil fertility, $50 \%$ of smallholders use manures. Most manure use is based on dung collection from livestock confined at homes. For this reason, those who do not use manures explain that the reason is the distance between their house and the plot. However, other forms of using manure include "bagazo" (agave wastes after preparing mescal) collection, dung collection from animals kept in the plot (Table 1), and purchase of manures $84.6 \%$ of manure users gather it in the months from January to June. The manure is taken to the plot, where it can be gathered in piles and exposed to sunlight, kept in sacks until needed, or directly put into the surface of the cultivated area. Collection from livestock is practiced by $53.3 \%$ of manure users. In one case, goats in a pen were observed within a cultivated area; this allows for easy collection and application of dung. However, this practice is not common because the animals require constant care, for which the distance from home to plot is an obstacle. Two farmers collect the agave "bagazo" and this is transformed into compost. Those who purchase manure obtain river moss and goat dung, and apply it to the surface of the cultivated area. The donkey is the most abundant animal and its dung is collected by the greatest number of farmers (Table 2). Although there are fewer goats, goat dung is applied to plots in the highest quantity. Peasants commented that the amount of manure applied overall is not enough for the cultivated areas, and that it is not applied every year.

Table 1. Manure used by smallholders. Including number of collectors of manure, people buying manure and average used ( $\mathrm{kg} / \mathrm{ha}$ )

\begin{tabular}{lccc}
\hline Manure & Collectors & Buyers & $\begin{array}{c}\text { Average } \\
\text { Use (kg/ha) }\end{array}$ \\
\hline Goat & 3 & 1 & 6600 \\
River Moss & 0 & 1 & 2906 \\
Donkey & 9 & 0 & 2096 \\
Cow & 3 & 0 & 2000 \\
Bagazo & 2 & 0 & 1600 \\
\hline
\end{tabular}

Table 2. Livestock released in plots.

\begin{tabular}{lccc}
\hline Livestock & Total & Released & Confined \\
\hline Donkeys & 56 & $75 \%$ & $25 \%$ \\
Sheep & 13 & $46 \%$ & $54 \%$ \\
Horses & 5 & $20 \%$ & $80 \%$ \\
Goats & 25 & $80 \%$ & $20 \%$ \\
Cows & 36 & $72 \%$ & $28 \%$ \\
\hline
\end{tabular}


When the first rains of the year fall (between May and June), manure is scattered in the cultivated area and sometimes only in places where the "milpa" grows insufficiently. Then the "barbecho" begins: this means that tillage is done with the help of a "yunta" (plough) pulled by donkeys, bulls or horses, to prepare soil for sowing. Some smallholders carry out a second "barbecho" before sowing or after harvesting to incorporate existing plants (weeds or crop remains) into the soil. However, the second "barbecho" is not common because of the physical demands of the work and economic costs.

After the harvest, $73.3 \%$ of the smallholders release their livestock from December to June (Figure 2). The reason for this practice is the economic savings it implies, since in the initial months of this period the animals feed from crop remains. However, this reduces the presence and decomposition of organic matter in plots. It also implies that the livestock dung and its nutrients will be deposited in other places outside the cultivated areas. For the next few months the livestock feed from wild fodder. The level of precipitation during the year regulates the number of crops and wild fodder, and thus the period that the livestock is released. Fences around the plots are important for maintaining soil fertility, as these prevent entry of livestock and preserving crop remains and wild fodder plants, and because plants forming fences may provide organic matter to the plot in the form of dry leaves and branches. However, only $43.3 \%$ of the smallholders have fences.

The general opinion about agrochemicals is that they are useful but not in San Luis Atolotitlán, because there is not a good precipitation and the crops cannot absorb them. Also, they are expensive, and only function now that they are used.
Smallholders think that manure is better because it constantly feeds the plant. Among those interviewed, only one farmer has irrigation and uses agrochemicals.

\section{Fallow management}

In addition, for recovering soil fertility, people use to practice fallows by rotating the cultivated areas in the plot: one or several areas are cultivated while another is left in fallow. Smallholders decide to leave the cultivated area fallow when maize productivity decreases, due to their perception of a "decreased strength of the soil." Nearly $27 \%$ of smallholders practice fallow of their cultivated areas. The rest do not because they depend on a constant crop production in all the cultivated areas of their plots, even if productivity is low. $62.5 \%$ of those who use the fallow method work a cultivated area for one year for each fallow year, others (25\%) work an area for 2 to 4 years per 1 to 2 fallow years, and just one person worked an area for 10 years followed by a fallow period of 7 years to date. Each time the fallow period ends, they repeat the clearing process, removing weeds and bushes but leaving perennial plants. The number and size of the plots available to a single farmer define the frequency and duration of fallows; smallholders with a small total cultivated area depend more on a constant crop production.

\section{Soil fertility}

The general information on soil fertility obtained from the 20 plots analyzed are shown in Tables 3-6 and the percentage of plots classified by soil fertility level are shown in Table 3. EC is very low or low in $95 \%$ of the cases, which means that salinity could not affect sensitive crops (Brady and 
Weil 2017). Most of the CEC values are adequate $(90 \%$ high or very high), which benefits the retention and cationic exchange of $\mathrm{K}, \mathrm{Ca}$, and $\mathrm{Mg}$ (Quiroga and Bono 2012). Since $60 \%$ of the $\mathrm{pH}$ values are high $(>7.80)$, soils are moderately basic, which reduces the solubility of micronutrients (Hagin and Tucker 1982). OM is apparently adequate, considering that in $95 \%$ of plots it is medium to very high and $\mathrm{N}$-t values are

Table 3. Percentage of plots classified by soil fertility level. Classification of parameters. VL: very low; L: low; $\mathrm{M}$ : medium; $\mathrm{H}$ : high; $\mathrm{VH}$ : very high

\begin{tabular}{lccccc}
\hline Parameter & VL & $\mathbf{L}$ & $\mathbf{M}$ & $\mathbf{H}$ & $\mathbf{V H}$ \\
\hline $\mathrm{CE}$ & 45 & 50 & 5 & 0 & 0 \\
$\mathrm{CEC}$ & 0 & 0 & 10 & 75 & 15 \\
$\mathrm{pH}$ & 0 & 0 & 15 & 75 & 10 \\
$\mathrm{MO}$ & 0 & 5 & 50 & 30 & 15 \\
$\mathrm{~N}-\mathrm{t}$ & 0 & 0 & 50 & 50 & 0 \\
$\mathrm{~N}-\mathrm{i}$ & 0 & 60 & 25 & 10 & 5 \\
$\mathrm{P}$ & 0 & 0 & 30 & 55 & 15 \\
$\mathrm{~K}$ & 5 & 0 & 35 & 60 & 0 \\
$\mathrm{Ca}$ & 0 & 0 & 0 & 0 & 100 \\
$\mathrm{Mg}$ & 0 & 0 & 5 & 45 & 60 \\
$\mathrm{Fe}$ & 15 & 65 & 20 & 0 & 0 \\
$\mathrm{Cu}$ & 20 & 40 & 25 & 10 & 5 \\
$\mathrm{Zn}$ & 90 & 10 & 0 & 0 & 0 \\
$\mathrm{Mn}$ & 0 & 5 & 25 & 40 & 30 \\
$\mathrm{~B}$ & 10 & 25 & 40 & 0 & 25 \\
\hline
\end{tabular}

also medium to high. However, this situation contrasts with the low levels of $\mathrm{N}-\mathrm{i}$ in $60 \%$ of plots, which indicates that some factor influencing on the decomposition of OM, like absence of water, is affecting the presence of $\mathrm{N}-\mathrm{i}$ in the soil (Celaya-Michel et al. 2011). $\mathrm{P}$ and $\mathrm{K}$ range from medium to very high in $95 \%$ of the plots; $\mathrm{Ca}$ is at very high levels; Mg values are high and very high in $95 \%$ of plots.

The sufficiency range of these nutrients is wide and crops are unlikely to have intoxication problems (Brady and Weil 2017). $\mathrm{Fe}, \mathrm{Cu}$, and $\mathrm{Zn}$ show insufficient (low or very low) levels in most plots; B values go from very low to very high, while it is concentrated at the medium level in $40 \%$. Deficiencies in $\mathrm{Fe}, \mathrm{Cu}$ and $\mathrm{Zn}$ could produce illness in the crops and a decrease in crop productivity (Azcón-Bieto and Talón 2008; Brady and Weil 2017).

\section{Agroforestry practices and soil fertility}

Nutrimental parameters are influenced by the amount of manure added to plots (Pillai's Trace: $F=20.45, \quad P=0.047$ ), and the interaction of the three agroforestry practices (Pillai's Trace: $F=96.61, P=0.010)$. The univariate ANOVAs (Table 4) showed that there were significant differences between the amount of manure and $\mathrm{N}-\mathrm{i}(\mathrm{P}=0.015), \mathrm{Cu}$ $(P=0.027)$, and $B(P=0.031)$. The amount of manure applied explained the variability of $\mathrm{N}-\mathrm{i}$ in $33.6 \%$, $\mathrm{Cu}$ in $26.7 \%$ and $\mathrm{B}$ in $26.1 \%$. Also, the interaction between vegetation cover, amount of manure and fallow years showed significant differences in Kvalues $(P=0.019)$ and explained the variability of $K$ in $18.6 \%$. Thus, and as shown in Figure 3, greater amounts of manure increase the quantity of $\mathrm{Ni}, \mathrm{Cu}$, and $\mathrm{B}$ in the cultivated areas. In the same way the interaction of vegetation cover, amount of manure and fallow years increase the presence of $\mathrm{K}$.

\section{DISCUSSION}

In many dry areas (arid and semiarid), agricultural intensification has decreased the vegetation cover (Harris 2002); however, $90 \%$ of the milpa-chichipera AFS plots present vegetation cover higher than $25 \%$; with these values, they are classified among 
Table 4. Analysis of variance (ANOVA) of from changes or perturbations from the nutrients related to agroforestry practices.

\begin{tabular}{lcccc}
\hline & Df & SS & $\boldsymbol{P}$ & $\mathbf{\%}$ \\
\hline N-i & & & & \\
Vegetation Cover (VC) & 1 & 0.056 & 0.141 & 10.650 \\
Amount of Manure (AM) & 1 & 0.177 & 0.015 & 33.650 \\
Fallow Years (FY) & 1 & 0.003 & 0.736 & 0.570 \\
VCxAM & 1 & 0.004 & 0.674 & 0.760 \\
VCxFY & 1 & 0.004 & 0.674 & 0.760 \\
AMxFY & 1 & 0.010 & 0.513 & 1.901 \\
VCxAMxFY & 1 & 0.004 & 0.674 & 0.760 \\
Error & 12 & 0.268 & & 50.950 \\
Total & 19 & 0.526 & & \\
K & & & & \\
Vegetation cover (VC) & 1 & 220 & 0.848 & 0.098 \\
Amount of Manure (AM) & 1 & 26165 & 0.054 & 11.700 \\
Fallow Years (FY) & 1 & 77383 & 0.003 & 34.590 \\
VCxAM & 1 & 83 & 0.906 & 0.037 \\
VCxFY & 1 & 965 & 0.689 & 0.431 \\
AMxFY & 1 & 8106 & 0.259 & 3.624 \\
VCxAMxFY & 1 & 41605 & 0.019 & 18.600 \\
Error & 12 & 69169 & & 30.920 \\
Total & 19 & 223696 & & \\
Cu & & & & \\
Vegetation cover (VC) & 1 & 0.02 & 0.851 & 0.150 \\
Amount of Manure (AM) & 1 & 3.568 & 0.027 & 26.700 \\
Fallow Years (FY) & 1 & 0.148 & 0.616 & 1.107 \\
VCxAM & 1 & 0.017 & 0.863 & 0.127 \\
VCxFY & 1 & 1.145 & 0.178 & 8.567 \\
AMxFY & 1 & 1.731 & 0.104 & 3.624 \\
VCxAMxFY & 1 & 0.027 & 0.829 & 12.950 \\
Error & 12 & 6.7092 & & 50.200 \\
Total & 19 & 13.365 & & \\
B & & & & \\
Vegetation cover (VC) & 1 & 0.358 & 0.446 & 2.700 \\
Amount of Manure (AM) & 1 & 3.463 & 0.031 & 26.120 \\
Fallow Years (FY) & 1 & 0 & 0.991 & 00 \\
VCxAM & 1 & 0.267 & 0.509 & 2.014 \\
VCxFY & 1 & 0.519 & 0.362 & 3.914 \\
AMxFY & 1 & 0.092 & 0.697 & 0.694 \\
VCxAMxFY & 1.619 & 0.120 & 12.210 \\
Error & & & & \\
Total & 13.941 & & 52.350 \\
\hline & & & \\
\hline
\end{tabular}

the world's top $5 \%$ of dry AFS in terms of vegetation cover (Zomer et al. 2009). Altieri and Toledo (2005) mention that ecosystem complexity on drylands is a key factor for maintaining the general equilibrium and resilience of the system. This characteristic creates different habitats, increases productivity, and recycles water and soil (Gliessman 2002; Vandermeer 2011). Besides, vegetation adapts and recovers environment (Gliessman 2002; Vandermeer 2011). Prior studies have proved the positive influence of trees on soil fertility in arid regions (Campbell et al. 1994; CelayaMichel et al. 2011; Ugboh and Ulebor 2011; Weltzin and Coughenour 1990); by providing organic matter, trees add nitrogen, phosphorus, and sulfur to the soil, they increase erosion resistance, and improve nutrient cycling and water infiltration (Campbell et al. 1994; Weil and Magdoff 2004). This may explain why a third of smallholders rely exclusively on wild vegetation management to maintain soil fertility.

Each household in San Luis Atolotitlán has on average 2.2 donkeys, 0.9 horses and 1.7 cows (Moreno-Calles et al. 2012), and only $50 \%$ of smallholders collect manure. Most of the manure users $(84.6 \%)$ do not make compost, but apply manure to the soil surface, which leads to nutrient leaching and volatilization (Brady and Weil 2017; Weil and Magdoff 2004). Additionally, smallholders comment that the quantity of manure is not enough for the cultivated area. The presence of a fence in the plots benefits conservation of organic matter, so its nutrients stay in the cultivated area (Hoffman et al. 2001; Williams 1999), but few smallholders can afford it. Even though the combination of manure and agrochemicals has had positive results in some dry regions (Place et al. 2002; Place et al. 2003), in the milpachichipera AFS agrochemicals are not used due to high costs, unawareness about their application and the absence of irrigation.

Fallows of 1-2 years for every 2-4 years of cultivation are practiced by one fourth of smallholders, although this is insufficient to reestablish fertility in dry zones because the proper length of time is a period of at least 20 years (Nair 1993). The absence of fallow 
Table 5. Soil fertility and management practices in milpa-chichipera plots.

\begin{tabular}{|c|c|c|c|c|c|c|c|c|c|}
\hline Plot & \multicolumn{3}{|c|}{ Soil Texture } & Soil Classification & EC & CEC & pH & OM & N-t \\
\hline & Sand & Silt & Clay & & & & & & \\
\hline & $\%$ & $\%$ & $\%$ & & dS & me/100g & & $\%$ & $\%$ \\
\hline 1 & 48.2 & 33.28 & 18.52 & Loam & 1.82 & 28.50 & 7.67 & 2.60 & 0.15 \\
\hline 2 & 50.2 & 35.28 & 14.52 & Loam & 2.00 & 26.25 & 7.51 & 3.40 & 0.14 \\
\hline 3 & 48.2 & 31.28 & 20.52 & Loam & 1.53 & 28.00 & 7.49 & 2.80 & 0.12 \\
\hline 4 & 38.2 & 33.28 & 28.52 & Clay loam & 1.45 & 43.50 & 7.53 & 2.30 & 0.13 \\
\hline 5 & 52.2 & 19.28 & 18.52 & Sandy Clay Loam & 2.77 & 15.60 & 7.90 & 3.90 & 0.19 \\
\hline 6 & 30.2 & 43.28 & 26.52 & Loam & 2.41 & 44.25 & 7.87 & 2.20 & 0.14 \\
\hline 7 & 40.2 & 37.28 & 22.52 & Loam & 1.33 & 27.00 & 7.27 & 9.40 & 0.16 \\
\hline 8 & 48.2 & 35.28 & 24.52 & Loam & 2.45 & 25.60 & 7.84 & 4.30 & 0.21 \\
\hline 9 & 56.2 & 29.28 & 14.52 & Sandy loam & 2.17 & 25.50 & 8.48 & 3.20 & 0.16 \\
\hline 10 & 40.2 & 35.28 & 24.52 & Loam & 2.77 & 29.75 & 8.16 & 8.50 & 0.13 \\
\hline 11 & 52.2 & 31.28 & 16.52 & Loam & 2.34 & 29.25 & 8.07 & 9.60 & 0.18 \\
\hline 12 & 54.2 & 31.28 & 16.52 & Sandy loam & 1.81 & 51.90 & 7.43 & 2.60 & 0.13 \\
\hline 13 & 70.2 & 21.28 & 8.52 & Sandy loam & 1.50 & 30.50 & 8.44 & 1.60 & 0.22 \\
\hline 14 & 60.2 & 27.28 & 12.52 & Sandy loam & 1.91 & 29.00 & 8.29 & 2.20 & 0.11 \\
\hline 15 & 70.2 & 19.28 & 10.52 & Sandy loam & 4.04 & 25.75 & 8.31 & 4.10 & 0.21 \\
\hline 16 & 44.2 & 37.28 & 18.52 & Loam & 1.48 & 25.00 & 7.24 & 3.90 & 0.19 \\
\hline 17 & 44.2 & 37.28 & 18.52 & Loam & 2.40 & 19.00 & 7.91 & 3.80 & 0.18 \\
\hline 18 & 42.2 & 25.28 & 32.53 & Clay loam & 1.78 & 30.75 & 7.38 & 3.10 & 0.16 \\
\hline 19 & 54.2 & 33.28 & 12.52 & Sandy loam & 2.15 & 39.40 & 8.27 & 2.20 & 0.12 \\
\hline 20 & 46.2 & 37.28 & 16.52 & Loam & 2.70 & 37.00 & 8.14 & 2.80 & 0.14 \\
\hline
\end{tabular}

Table 6. Nutrient analysis and management practices in milpa/chicipera plots.

\begin{tabular}{|c|c|c|c|c|c|c|c|c|c|c|c|c|c|}
\hline Plot & $\mathbf{N}-\mathbf{i}$ & $\mathbf{P}$ & $\mathbf{K}$ & $\mathbf{C a}$ & Mg & $\mathbf{F e}$ & $\mathrm{Cu}$ & $\mathbf{Z n}$ & Mn & B & Vegetation & Manure & Fallow \\
\hline & \multicolumn{10}{|c|}{$\mathrm{mg} \mathrm{kg}^{-1}$} & $\%$ & $\mathrm{Kg} / \mathrm{ha}^{-1}$ & years \\
\hline 1 & 5.60 & 22.2 & 320 & 6884 & 895 & 9.56 & 0.68 & 0.38 & 32.66 & 2.23 & 10.38 & 2682 & 1 \\
\hline 2 & 8.40 & 18.3 & 74 & 3842 & 690 & 10.63 & 0.19 & 0.32 & 30.78 & 0.89 & 54.82 & 0 & 2 \\
\hline 3 & 4.20 & 21.4 & 191 & 5718 & 609 & 10.63 & 0.33 & 0.44 & 27.78 & 1.02 & 44.59 & 0 & 0 \\
\hline 4 & 18.20 & 31 & 250 & 4022 & 450 & 7.63 & 1.35 & 0.47 & 34.95 & 0.83 & 42.01 & 0 & 0 \\
\hline 5 & 8.40 & 23 & 390 & 3914 & 2223 & 10.45 & 0.48 & 0.86 & 21.69 & 1.34 & 45.13 & 0 & 0 \\
\hline 6 & 7.00 & 19.9 & 168 & 3084 & 306 & 2.99 & 0.24 & 0.30 & 33.66 & 0.06 & 35.85 & 0 & 0 \\
\hline 7 & 7.00 & 19.1 & 117 & 3122 & 754 & 13.98 & 0.27 & 0.40 & 37.41 & 0.95 & 27.13 & 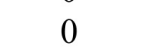 & 1 \\
\hline 8 & 5.60 & 15.9 & 207 & 4738 & 553 & 12.26 & 1.07 & 0.35 & 27.16 & 0.89 & 15.30 & 0 & 2 \\
\hline 9 & 5.60 & 19.9 & 425 & 4720 & 771 & 1.83 & 0.44 & 0.25 & 12.34 & 1.14 & 43.90 & 1296 & 0 \\
\hline 10 & 14.00 & 15.9 & 242 & 3528 & 791 & 5.89 & 2.37 & 0.15 & 12.88 & 1.02 & 46.94 & 896 & 0 \\
\hline 11 & 18.20 & 42.1 & 398 & 4034 & 993 & 9.46 & 0.78 & 0.49 & 26.07 & 2.99 & & 75 & 0 \\
\hline 12 & 21.00 & 18.3 & 133 & 4086 & 3259 & 10.72 & 1.19 & 0.37 & 33.60 & 0.06 & 52.38 & 2413 & 0 \\
\hline 13 & 7.00 & 12.7 & 300 & 5726 & 1384 & 6.17 & 0.68 & 0.17 & 9.32 & 1.08 & 49.05 & 0 & 0 \\
\hline 14 & 5.60 & 15.1 & 215 & 5294 & 442 & 6.27 & 0.80 & 0.21 & 7.48 & 0.64 & 48.24 & 0 & 0 \\
\hline 15 & 54.60 & 23 & 172 & 5190 & 1728 & 1.11 & 3.93 & 0.34 & 20.06 & 3.18 & 41.73 & 6034 & 2 \\
\hline 16 & 4.20 & 25.4 & 238 & 3870 & 866 & 16.26 & 0.28 & 0.28 & 24.57 & 1.27 & 48.27 & 450 & 0 \\
\hline 17 & 12.60 & 31.8 & 277 & 4618 & 2084 & 10.45 & 0.97 & 0.52 & 10.27 & 1.21 & 48.75 & 1508 & 0 \\
\hline 18 & 15.40 & 15.1 & 273 & 3128 & 607 & 12.06 & 0.38 & 0.43 & 40.90 & 1.02 & 48.96 & 1156 & 0 \\
\hline 19 & 5.60 & 15.1 & 257 & 3982 & 2416 & 7.56 & 0.98 & 0.21 & 12.82 & 2.54 & 35.31 & 0 & 0 \\
\hline 20 & 28.00 & 26.2 & 499 & 5304 & 1014 & 6.42 & 1.21 & 0.45 & 20.94 & 2.93 & 51.07 & 7168 & 0 \\
\hline
\end{tabular}



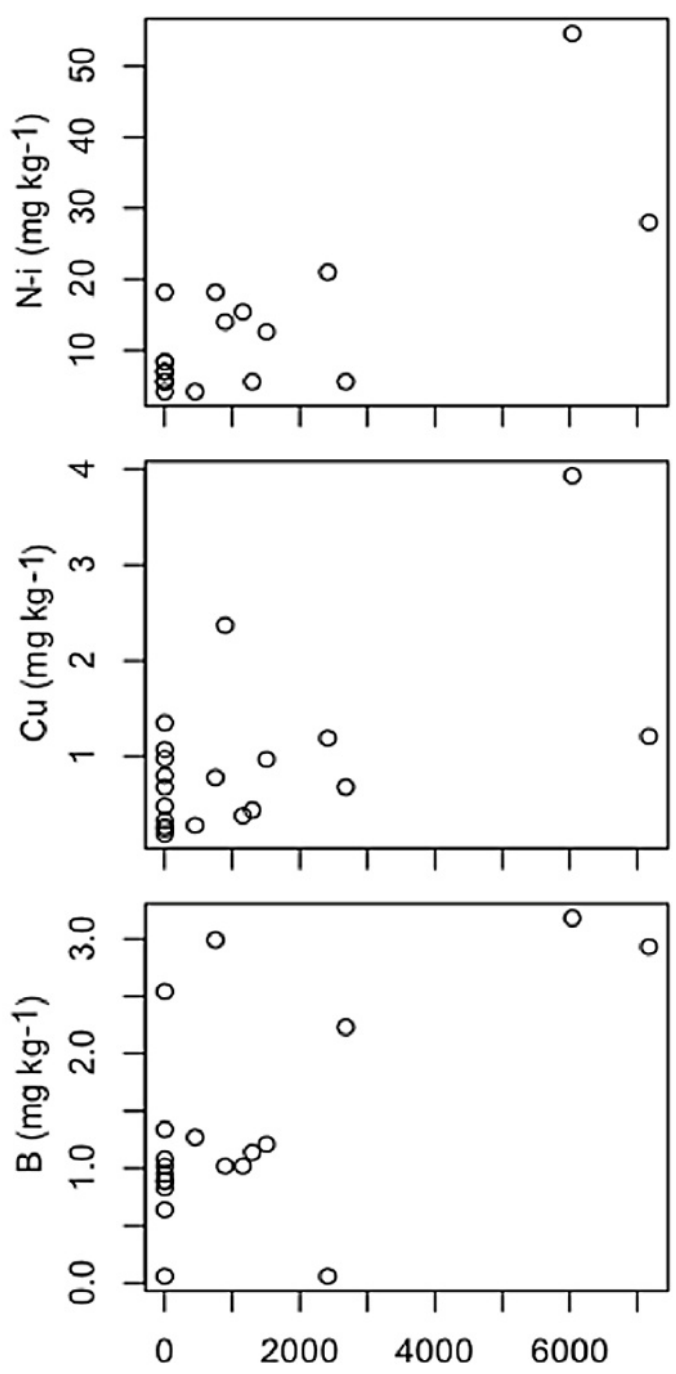

Amount of manure $(\mathrm{kg} / \mathrm{ha})$

Figure 3. Influence of amount of manure on $\mathrm{N}-\mathrm{i}$, $\mathrm{Cu}$ and $\mathrm{B}$.

management in most smallholders' practice could be due to socio-economic pressures to increase crop productivity (Hoffman et al. 2001). Long periods of cropping with short or nonexistent fallow periods can result in decrease of crop productivity and soil degradation (Styger and Fernandes 2006). Some households have more than one agricultural plot and, as mentioned by Tittonell et al. (2005), use the closest plot to home more intensely, leaving the distant plot in more extended fallows; they comment that the difference in use is due to limitations on labor force and economic resources.

The agroforestry management practices are diverse and irregular, but conserve organic matter in adequate values in $95 \%$ of plots. Considering the lack of agrochemical use, organic matter is fundamental for maintaining soil fertility in the AFS. In comparison with other dry agricultural sites in Mexico, in milpa-chichipera plots, $\mathrm{OM}, \mathrm{Ca}$, and $\mathrm{Mg}$ values are among the highest (Table 7 ); but $\mathrm{N}-\mathrm{i}, \mathrm{P}$ and $\mathrm{K}$ values are among the lowest, although $\mathrm{P}$ and $\mathrm{K}$ are adequate fertility values. $\mathrm{N}-\mathrm{i}$ deficiency is characteristic of dry regions (Chapin et al. 2002; Whitford 1993), but milpa-chichipera AFS has high levels of $\mathrm{OM}$ and $\mathrm{N}-\mathrm{t}$, and low levels of $\mathrm{N}-\mathrm{i}$. Thus, to increase $\mathrm{N}-\mathrm{i}$ levels it is important to improve collection, processing, and application of organic matter (Harris 2002). Due to basic soil $\mathrm{pH}$, micronutrient deficiencies can be improved with a foliar fertilization (Hagin and Tucker 1982), however economic constraints could be an obstacle. Brady and Weil (2017) suggest that the effect of manure application on the soil fertility is greater through micronutrients rather than $\mathrm{N}-\mathrm{P}-\mathrm{K}$ content.

Considering the positive relation of manure and the three agroforestry practices with $\mathrm{N}-\mathrm{i}, \mathrm{K}, \mathrm{Cu}$ and $\mathrm{B}$, people can improve fertility if they increase the amount of manure applied and carry out the three agroforestry practices. However, sociocultural conditions have to be considered when proposing changes of agroforestry practices (Parr et al. 1990; Koohafkan and Stewart 2008). Several interviewees mentioned that low crop productivity is caused by lack of rainfall and not by soil infertility; because when precipitation is good, crop productivity is normal. These testimonies, along with 
Table 7. Average fertility values of agricultural soils in dry zones of México including OM, P, K, Ca and Mg.

\begin{tabular}{|c|c|c|c|c|c|c|c|c|}
\hline Reference & Location & Site & OM \% & $\mathbf{N}-\mathbf{i}$ & ${\text { P } \text { mg kg }^{-1}}^{-1}$ & $\mathbf{K}$ & $\mathbf{C a}$ & Mg \\
\hline \multicolumn{9}{|l|}{ Present study } \\
\hline & Tehuacán Valley & 1 & 3.9 & 12.8 & 21.5 & 257 & 4440 & 1141 \\
\hline \multicolumn{9}{|c|}{ López-Galindo et al. } \\
\hline \multirow[t]{4}{*}{2003} & Tehuacán Valley & 1 & 1.3 & - & - & 1131 & 2620 & 713.9 \\
\hline & Tehuacán Valley & 2 & 2.2 & - & - & 897 & 3580 & 617.1 \\
\hline & Tehuacán Valley & 3 & 1.2 & - & - & 468 & 2440 & 532.4 \\
\hline & Tehuacán Valley & 4 & 3.9 & - & - & 1170 & 4492 & 363.0 \\
\hline \multirow[t]{4}{*}{ López et al.2003 } & Vizcaíno Desert & 1 & 0.2 & 20.5 & 84.7 & 156 & 690 & 96.8 \\
\hline & Vizcaíno Desert & 2 & 0.5 & 65.7 & 52.4 & 1852 & 2980 & 1306.8 \\
\hline & Vizcaíno Desert & 3 & 0.7 & 72.0 & 43.1 & 1298 & 3640 & 1101.1 \\
\hline & Vizcaíno Desert & 4 & 0.3 & 43.6 & 48.2 & 936 & 920 & 544.5 \\
\hline
\end{tabular}

findings of adequate levels of macronutrients $(\mathrm{N}-\mathrm{t}, \mathrm{P}, \mathrm{K}, \mathrm{Ca}$ and $\mathrm{Mg}$ ) indicate that soil fertility in the milpa-chichipera AFS is sufficient and crop productivity is not affected. Because the agroforestry practices are diverse and irregular it is difficult to establish the impact of each one on the fertility parameters.

Thus, it is important to increase the number of plots studied and to measure the contribution of organic matter from vegetation, the quality and quantity of manure applied and the impact of plant species in the fallow process. The studies on these AFS shows that milpa-chichipera complexity satisfies most of the food needs of farmers and their families (Moreno-Calles et al. 2010, 2012). Also support the idea that traditional practices can achieve a sustainable use of soil and forest. For this reasons desertification is not a problem.

\section{Perspectives}

The milpa chichipera AFS it is being transformed due to the decreasing species richness and vegetation cover, reduction of plots and overuse of cultivated land
(Moreno-Calles et al. 2013). Additionally, the scarcity of money, labor force and governmental support, comprises traditional agroforestry management and will result in more problems to replenish soil nutrients. This situation could put at risk the AFS productivity and cause desertification. Local people have the knowledge to preserve soil fertility and their practices can be improved with agroecological support. Unfortunately, governmental institutions promote an industrial agriculture that do not support the traditional practices (Moreno-Calles et al. 2012). The goal of this kind of research is to contribute to an understanding of the milpachichipera AFS in an integral way. The collaboration of researchers and authorities is necessary to conduct dialogues with smallholders, as are economic support and adequate government policies, with the purpose of improving management and conservation of the milpa-chichipera AFS.

\section{CONCLUSIONS}

Traditional practices in the milpachichipera system are diverse and heterogeneous, but maintain soil fertility at 
sufficient levels for maintaining long-term agriculture. Wild vegetation and high plant diversity is essential for the replenishment of soil nutrients. Agroforestry management allows a sustainable use of soil and forest. If socio-economic pressures continue, ethnoagroforestry agroforestry management will diminish and soil fertility and crop productivity will be at risk of desertification. Manure application and the interaction of agroforestry practices influence in the presence of soil nutrients $(\mathrm{N}-\mathrm{i}, \mathrm{K}, \mathrm{Cu}$, and $\mathrm{B})$. $A$ deeper understanding of the management practices performed by local people and their relationship with soil fertility together with participatory agroecological approaches are necessary to improve agroecosystem management.

\section{ACKNOWLEDGMENTS}

The authors thank the Posgrado en Agroforestería para el Desarrollo Sostenible and CONACYT for supporting the postgraduate studies of the first author. We appreciate the financial support of field work of Posgrado Chapingo and DGAPA UNAM (projects PAPIIT IN200417 and PAPIME 209517). Also, thanks to Lorenzo and María Ortega for supporting field work, and Atish "Taku" Chakravarti for helping in the translation of the manuscript. Finally, we sincerely thank the people of San Luis Atolotilán, especially the Ortega family, for their hospitality and friendship.

\section{REFERENCES}

Altieri MA (1991) ¿Por qué estudiar la agricultura tradicional? Agroecología y Desarrollo 1: 16-24

Altieri MA (2004) Linking ecologists and traditional farmers in the search for sustainable agriculture. Frontiers in Ecology and Environment 2: 35-42

Altieri MA, Nicholls NI (2005) Agroecology and the search for a truly sustainable agriculture. 1ed. United Nations Environment Programme, Mexico City, Mexico

Altieri MA, Toledo VM (2005) Natural resource management among small-scale farmers in semi-arid lands: building on traditional knowledge and agroecology. Annals of Arid Zone 44: 365-385

Ankerman D, Large R (1977) Soil and plant analysis. 1 ed. Agricultural Laboratories, Memphis, USA

Azcón-Bieto J, Talón M (2008) Fundamentos de Fisiología Vegetal. 1 ed. McGraw-Hill, Madrid, Spain

Blancas J, Casas A, Rangel-Landa S, MorenoCalles A, Torres I, Pérez-Negrón E, Solís L, Delgado-Lemus A, Parra F, Arellano Y, Caballero J, Cortés L, Lira R, Dávila P (2010) Plant managment in the Tehuacán-Cuicatlán Valley, México. Economic Botany 4: 287-302

Brady NC, Weil RR (2017) The nature and properties of soils. 15 ed. Pearson Prentice Hall, New Jersey, USA

Campbell BM, Frost P, King JA, Mawanza M, Mhlanga $L$ (1994) The influence of trees on soil fertility on two contrasting semi-arid soil types at Matopos, Zimbawe. Agroforest Systems 28: 159-172

Campos-Salas N, Casas A, Moreno-Calles Al, Vallejo M (2016) Plant management in agroforestry systems of rosetophyllous forests in the Tehuacán Valley, Mexico. Economic Botany 70: 254-269

Cariño M, Castorena L, Maya Y, Wurl J, Urciaga J, Breceda A (2012) Transformación de los ecosistemas áridos para su uso agrícola en Baja California Sur, México. Un análisis desde la historia ambiental. Historia Agraria 56: 81106

Casas A, Caballero J, Mapes CS (1997) Manejo de la vegetación, domesticación de plantas y origen de la agricultura en Mesoamérica. Boletín de la Sociedad Botánica de México 61: 31-47

Casas A, Otero-Arnaiz A, Pérez-Negrón E, Valiente-Banuet A (2007) In situ management and domestication of plants in Mesoamerica. Annals of Botany 100: 1101-1115 
Casas A, Valiente-Banuet A, Solís L, PérezNegrón E (2010) El manejo de la biodiversidad en el desierto: El Valle de TehuacánCuicatlán. In: Toledo VM (ed.) La Biodiversidad de México. 1 ed. Fondo de Cultura Económica, México City, México, pp. 235-272

Casas A, Valiente-Banuet A, Viveros JL, Caballero J, Cortés L, Dávila $P$, Lira $R$, Rodríguez I (2001) Plant resources of the Tehuacán-Cuicatlán valley, México. Economic Botany 55: 129-166

Celaya-Michel H, Castellanos-Villegas AE (2011) Mineralización de nitrógeno en el suelo de zonas áridas y semiáridas. Terra Latinoamericana 29: 343-356

Chapin FS, Matson PA, Mooney HA (2002) Principles of terrestrial ecosystem ecology. 2 ed. Springer, New York, USA

Dávila $P$, Arizmendi MC, Valiente-Banuet $A$, Villaseñor JL, Casas A, Lira R (2002) Biological diversity in the Tehuacán-Cuicatlán Valley, Mexico. Biodiversity and Conservation 11: 421 442

Ffolliott PF, Brooks KN, Gregersen HM, Lundgren $\mathrm{AL}$ (1995) Dryland forestry: Planting and management. 1 ed. John Wiley, New York, USA

Geist HJ, Lambin EF (2004) Dynamic causal patterns of desertification. Bioscience 54: 817829

Granados-Sánchez D, López-Ríos GF, Hernández-Hernández J (2004) Agricultura nhanñhu-otomí del Valle de Mezquital, Hidalgo. Terra Latinoamericana 22: 117-126

Gliessman SR (2002) Agroecología: procesos ecológicos en agricultura sostenible. $1 \mathrm{ed}$. CATIE, Turrialba, Costa Rica

Hagin J, Tucker B (1982) Fertilization of dryland and irrigated soils. 1 ed. SpringerVerlag, New York, USA

Haileslassie A, Priess JA, Veldkamp E, Lessehen JP (2006) Smallholders' soil fertility management in the central highlands of Ethiopia: implications for nutrient stocks, balances, and sustainability of agroecosystems. Nutrient Cycling in Agroecosystem 75: 135-146

Harris E (2002) Management of manure in farming systems in semi-arid West Africa. Experimental Agriculture 38: 131-14

Hoffmann, I, Gerling D, Kyiogwom US, Mané-
Bielfeldt A (2001) Farmers' management strategies to maintain soil fertility in a remote area in northwest Nigeria. Agriculte, Ecosystem and Environment 86: 263-275

Jock RA, Dillon JL (1992) Risk analysis in dryland farming systems. Food and Agriculture Organization 2: 1-109

Kassas M (1995) Desertification: a general review. Journal of Arid Environments 30: 115128

Krebs C (1998) Ecological methodology. 2 ed. Adisson-Welsey educational publishers, New York, USA

Koohafkan P, Stewart BA (2008) Water and cereals in drylands. Food and Agriculture Organization and Earthscan, Sterling, USA

López $R$, Villavicencio-Floriani E, Real-Rosas MA, Ramírez-Barajas J, Murillo-Amador B (2003) Macronutrimentos en suelos de desierto con potencial agrícola. Terra Latinoamaericana 21: 333-340

López-Galindo F, Muñoz-Iniestra D, HernándezMoreno M, Soler-Aburto A, Castillo-López MC, Hernández-Arzate I (2003) Análisis integral de la toposecuencia y su influencia en la distribución de la vegetación y la degradación del suelo en la subcuenca de Zapotitlán Salinas, Puebla. Boletín de la Sociedad Geológica Mexicana 56: 19-41

Maya Y, Coria R, Domínguez R, Arriaga L, Rodríguez-Estrella R (1997) Caracterización de los oasis. In: Arriaga L, Rodríguez-Estrella R (eds.) Los oasis de la Península de Baja California. 1 ed. Centro de Investigaciones Biológicas del Noroeste- SIMAC, La Paz, Mexico, pp. 5-25

Moreno-Calles Al, Casas A (2008) Conservación de biodiversidad y sustentabilidad en sistemas agroforestales de zonas áridas del valle de Tehuacán, México. Zonas Áridas 12: 13-35

Moreno-Calles AI, Casas A, Blancas J, Torres I, Masera O, Caballero J, García-Barrios L, PérezNegrón E, Rangel-Landa S (2010) Agroforestry systems and biodiversity conservation in arid zones: the case of the Tehuacán Valley, Central México. Agroforest System 80: 315-331

Moreno-Calles Al, Casas A, Torres-García I, García-Frapolli E (2012) Traditional agroforestry systems of multicrop milpa and chichipera cactus forest in the arid Tehuacán 
Valley, México: Their management and role in people's subsistence. Agroforest System 84: 207-226

Moreno-Calles AI, Toledo VM, Casas A (2013) Los sistemas agroforestales tradicionales de México: una aproximación biocultural. Botanical Science 91: 375-398

Moreno-Calles AI, Casas A, Rivero-Romero AD, Romero Y, Fisher Ortíz RA, Alvarado F, Vallejo M, Santos-Fita Dc (2016a) Ethnoagroforestry: Integration of biocultural diversity for sovereignty (food) in

Mexico. Journal of Ethnobiology and Ethnomedicine 12: 2-21

Moreno-Calles AI, Casas A, Toledo VM, VallejoRamos M (2016b) Etnoagroforestería en México. 1 ed. UNAM, Morelia, Mexico

Nair PKR (1993) An introduction to agroforestry. 1 ed. Kluwer academic publishers, Dordrecht, The Netherlands

Parr JF, Stewart BA, Hornick SB, Singh RP (1990) Improving the sustainability of dryland farming systems: a global perspective. Advances in Soil Science 13: 1-8

Palerm JV (1997) La persistencia y expansion de sistemas agrícolas tradicionales: El caso de huamil en el Bajio mexicano. Monografias del Jardín Botánico de Córdoba 5:121-133

Place F, Franzel S, Dewolf J, Rommelse R, Kwesiga F, Niang A, Jama A (2002) Agroforestry for soil fertility replenishment: evidence on adoption processes in Kenya and Zambia. In: Barret CB, Place F, Aboud AA (eds.) Natural resources management in African agriculture: understanding and improving current practices. CABI, ICRAF, New York, USA, pp. 155-168

Place F, Barrey CB, Freeman HA, Ramisch JJ, Vanlauwe B (2003) Prospects for integrated soil fertility management using organic and inorganic inputs: evidence from smallholder African agricultural systems. Food Policy 28: 365-378

Pretty JN (1995) Regenerating agriculture: policies and practice for sustaintability and self-reliance. 1 ed. Joseph Henry, London, UK

Quinn GP, Keough MJ (2002) Experimental design and data analysis for biologists. 1 ed. Cambridge University Press, Cambridge, UK

Quiroga A, Bono A (2012) Manual de fertilidad y evaluación de suelos. 1 ed. Instituto Nacional de Tecnología Agropecuaria, Buenos Aires,
Argentina

R Development Core Team 2011 R: A Language and Environment for Statistical Computing. R Foundation for Statistical Computing, Vienna, Austria. URL http://www.R-project.org/.

Reynolds JF, Maestre FT, Huber-Sanwald E, Herrick J, Kemp PR (2005) Aspectos socioeconómicos y biofísicos de la desertificación. Ecossistemas 14: 3-21

SEMARNAT (2002) Norma Oficial Mexicana NOM-021-SEMARNAT-2000. Publishing Secretaría de Medio Ambiente y Recursos Naturales de México. http://dof.gob.mx/nota_detalle.php?codigo=7175 82\&fecha $=31 / 12 / 2002$ Accessed 20 October 2013

Scheiner SM (2001) MANOVA, multiple response variables and multiespecies interactions. In: Scheiner SM, Gurevitch J (eds.) Design and analysis of ecological experiments. 2 ed. Oxford University Press, New York, USA, pp. 94-112

Styger E, Fernandes ECM (2006) Contributions of managed fallows to soil fertility recovery. In: Uphoff $N$, Ball AS, Fernandes $E$, Herren $H$, Husson O, Laing M, Palm C, Pretty J, Sanchez PA, Sanginga N, Thies JE (eds.) Biological approaches to sustainable soil systems. $1 \mathrm{ed}$. CRC, Taylor \& Francis, Florida, USA, pp. 425-437

Tittonell P, Vanlauwe B, Leffelaar PA, Rowe EC, Shepherd KD (2005) Exploring diversity in soil fertility management of smallholder farms in western Kenya I. Heterogeneity at region and farm scale. Agriculture Ecosystem and Environment 110: 149-165

Toledo VM, Ortiz-Espejel B, Cortés L, Moguel PMDJ (2003) The multiple use of tropical forests by idigenous people in Mexico: a case of adaptive management. Conservation Ecology 7: 1-9

Toledo VM, Barrera-Bassols N (2008) La memoria biocultural: La importancia ecológica de las sabidurías tradicionales. 1 ed. Icaria Editorial, Madrid, España

Torres I (2004) Aspectos ecológicos y etnobotánicos de los recursos vegetales en el Valle de Tehuacan-Cuicatlán. Msc. dissertation, Michoacana de San Nicolás de Hidalgo University, Morelia, México

Vallejo-Ramos M, Moreno Calles AI, Casas A 
(2016) TEK and biodiversity management in agroforestry systems by different human cultures. Journal of Ethnobiology and Ethnomedicine 12:1-15

Vallejo-Ramos $M$, Casas A, Pérez-Negrón $E$, Moreno-Calles Al, Hernández Ordoñez O, Dávila OT P (2015) Agroforestry systems of the lowland alluvial valleys of the TehuacánCuicatlán Biosphere Reserve: an evaluation of their biocultural capacity. Journal of Ethnobiology and Ethnomedicine 11:8

Valiente-Banuet A, Dávila P, Casas A, Arizmendi MC, Ortega-Ramírez J (2006) Diversidad biológica y desarrollo sustentable en la reserva de la biosfera Tehuacán Cuicatlán. In: Oyama K, Castillo A (eds.) Manejo, conservación y restauración de recursos naturales en México: Perspectivas de la Investigación Científica. 1 ed. Editorial siglo xxi, Mexico City, pp. 248-277

Ugboh O, Ulebor JU (2011) Application of integrated soil fertility approach in the improvement of soil fertility in semi-arid ecology. Journal of Agriculture and Social Research 11: 81-86

Vandermeer JH (2011) The ecology of agroecosystems. 1 ed. Jones and Bartlett Publishers,USA

Weil RR, Magdoff F (2004) Significance of soil organic matter to soil quality and health. In: Magdoff F, Weil RR (eds.) Soil organic matter in sustainable agriculture. 1 ed. CRC Press, Florida, USA, pp. 1-44

Weltzin JF, Coughenour MB (1990) Savanna tree influence on understory vegetation and soil nutrients in northwestern Kenya. Journal of Vegetation Science 1: 325-334

\section{Whitford DT, Pastor J (1993) Nitrogen mineralization dynamics in grass monocultures. Oecología 96: 186-192}

Williams T (1999) Factor influencing manure application by farmers in semi-arid west Africa. Nutrient Cycling in Agroecosystem 55: $15-22$

Young A (1997) Agroforestry for soil management. 2 ed. CAB International, Wallingford, UK

Zomer RJ, Trabucco A, Coe R, Place F (2009) Trees on farm: Analysis of global extent and geographical patterns of agroforestry. ICRAF, 89 ed. Nairobi, Kenia
Received: 21 November 2016

Accepted: 01 February 2017

Published: 26 June 2017 